\title{
QUANTITATIVE EVALUATION OF ACIDITY TOLERANCE OF ROOT NODULE BACTERIA
}

\author{
Luiz Antonio de Oliveira*; Hélio Paracaima de Magalhães
}

\author{
Coordenação de Pesquisas em Ciências Agronômicas, Instituto Nacional de Pesquisas da Amazônia, \\ Manaus, AM, Brasil
}

Submitted: May 05, 1998; Returned to authors for corrections: September 24, 1998; Approved: May 28, 1999

\begin{abstract}
Quantification of acidity tolerance in the laboratory may be the first step in rhizobial strain selection for the Amazon region. The present method evaluated rhizobia in Petri dishes with YMA medium at pH 6.5 (control) and 4.5, using scores of 1.0 (sensitive, "no visible" growth) to 4.0 (tolerant, maximum growth). Growth evaluations were done at $6,9,12,15$ and 18 day periods. This method permits preliminary selection of root nodule bacteria from Amazonian soils with statistical precision. Among the 31 rhizobia strains initially tested, the INPA strains 048,078 , and 671 presented scores of 4.0 at both $\mathrm{pHs}$ after 9 days of growth. Strain analyses using a less rigorous criterion (growth scores higher than 3.0) included in this highly tolerant group the INPA strains $511,565,576,632,649$, and 658 , which grew on the most diluted zone (zone 4) after 9 days. Tolerant strains still must be tested for nitrogen fixation effectiveness, competitiveness for nodule sites, and soil persistence before their recommendation as inoculants.
\end{abstract}

Key words: rhizobia, tolerance to $\mathrm{pH}$, Amazon.

\section{INTRODUCTION}

The majority of Amazon Basin soils are acid and have low fertility. Soil $\mathrm{pH}$ is usually $4.0-4.5$, and $\mathrm{P}$, $\mathrm{N}, \mathrm{Ca}, \mathrm{K}, \mathrm{Mg}$ are deficient in most plateau soils of the Amazon. It is estimated that $\mathrm{P}$ and $\mathrm{N}$ are deficient in $90 \%$ of the regional soils (4). Agricultural, forestry and agroforestry yields are negatively affected by these constraints. Liming and fertilization are practiced by only a few landowners, because these amendments are expensive and difficult to obtain in the region, especially for small farmers (14).

Nitrogen fixation by legume-rhizobia symbioses may supply nitrogen to the ecosystem, but plants and bacteria must tolerate soil constraints, such as acidity and $\mathrm{Al}$ toxicity. Legume nodulation under natural soil fertility is sparse or absent $(3,7)$, except when soil constraints are eliminated (6). Bradyrhizobium strains have been selected for their tolerance to low $\mathrm{pH}$ and low soil fertility $(1,2,16,17)$ for practical use in agriculture and forest systems. However, these methods do not quantify the rhizobia's tolerance to acidity.

Colony counting of rhizobia grown in acid YM liquid medium is a possibility, but it is very difficult and expensive in terms of material and time for screening a large number of strains or isolates. To facilitate strain selection, a fast and easy method is necessary to evaluate a large number of isolates, as well as to quantify bacterial tolerance/sensitivity to

* Corresponding author. Mailing address: INPA, Caixa Postal 478, CEP 69011-970, Manaus, AM, Brasil. E-mail: luizoli@inpa.gov.br 
these soil constraints. The objective of the present study was to test a laboratory method for this purpose as the first step in selection of root nodule bacteria for acid soils. The goal is to eliminate those strains that are acid sensitive, thus decreasing the number of isolates for other tests, such as root infection, host effectiveness, nodule competitiveness, and soil persistence $(5,8,9,10,11)$, which will be done only for those which present high tolerance to acidity. This procedure may shorten evaluation time and decrease costs in the process of rhizobia selection.

\section{MATERIALS AND METHODS}

The present method evaluated several root nodule bacteria strains in Petri dishes with YMA medium $(15,18)$ using an adaptation of a method for streaking rhizobia (15) at two pHs, 4.5 and 6.5 (control). These rhizobia were isolated from different legume plant species and Amazonian soil conditions (Table 1). For adequate solidification, YMA acid medium ( $\mathrm{pH} 4.5$ ) was prepared with $25 \mathrm{~g}$ of agar/L, instead of the usual $15 \mathrm{~g}$. The media were not buffered, so as to find strains which are able to modify the $\mathrm{pH}$. This bacterial ability may be important under soil conditions, where all tolerance mechanisms may help their survival and soil colonization. Rhizobia isolates were streaked from a mother Petri dish with YMA (pH 6.5, where bacteria were growing during a five day period) with a platinum loop. Four replicates were used for each rhizobia isolate in each pH medium. Fig. 1 presents the general streaking procedure, which used only one loop per replication from the mother Petri dish. A dilution factor occurs when looping is done from one zone to the other, so zone 4 is the most diluted. Fig. 2 presents the scoring system: 1.00 - "no" growth (no visible growth); 1.25 - some growth only in zone 1; 2.00 - maximum growth in zones 1 and 2; 3.00 maximum growth in zones 1 to $3 ; 4.00$ - maximum growth in all four zones. Intermediate scores were also given at intervals of 0.25 . Growth evaluations were done until score stabilization, which occurred 6-18 days after streaking in the plates. Statistical analyses of growth were done at $6,9,12,15,18$ days after streaking, using the $\mathrm{F}$ test and Tukey at $5 \%$ for mean comparisons. This method also permits a less rigorous analysis, which consisted of the interpretation given in Table 2, with the best strains presenting scores higher than 3.00. A total of 31 strains were tested by this method. A second test consisted of adding green bromocresol solution to the acid medium to verify possible $\mathrm{pH}$ modification during bacterial growth. A visual change may be seen when $\mathrm{pH}$ changes from the initial value of 4.5 (bromocresol changes to yellow color at $\mathrm{pHs}$ below 4.5 , and becomes green/blue at higher $\mathrm{pHs}$ ).

Table 1. Host species and procedence of rhizobia tested on the YMA medium.

\begin{tabular}{|c|c|c|}
\hline STRAINS* & HOST SPECIES & PROCEDENCE \\
\hline INPA 029 & Vigna unguiculata & Várzea Ariaú/Solimões \\
\hline INPA 044 & Vigna unguiculata & FUCADA/Ultisol \\
\hline INPA 046 & Vigna unguiculata & FUCADA/Ultisol \\
\hline INPA 048 & Vigna unguiculata & Várzea Ariaú/Solimões \\
\hline INPA 055 & Vigna unguiculata & Várzea Ariaú/Solimões \\
\hline INPA 078 & Vigna unguiculata & FUCADA/PVA \\
\hline INPA 511 & Ormosia excelsa & INPA/CPCA \\
\hline INPA 520 & Pithecellobium saman & Maracá/RR \\
\hline INPA 522 & Clitoria sp. & Maracá/RR \\
\hline INPA 526 & Platymiscium paraensis & Maracá/RR \\
\hline INPA 550 & Inga edulis & Calado Lake/AM \\
\hline INPA 558 & Pithecellobium latifolium & Anavilhanas/AM \\
\hline INPA 562 & Pithecellobium latifolium & Anavilhanas/AM \\
\hline INPA 563 & Acacia multipinnata & Maracá/RR \\
\hline INPA 565 & Rhynchosia minima & Ariaú/AM \\
\hline INPA 568 & Dalbergia inundata & Anavilhanas/AM \\
\hline INPA 576 & Galactia jussiaeana & Maracá/RR \\
\hline INPA 602 & Enterolobium maximum & Anavilhanas/AM \\
\hline INPA 609 & Swartzia laevicarpa & Anavilhanas/AM \\
\hline INPA 624 & Swartzia laevicarpa & Anavilhanas/AM \\
\hline INPA 630 & Pithecellobium latifolium & INPA/CPCA \\
\hline INPA 632 & Centrolobium paraensis & INPA/CPCA \\
\hline INPA 641 & Pithecellobium inaequale & INPA/CPCA \\
\hline INPA 642 & Cassia mimosoides & Anavilhanas/AM \\
\hline INPA 649 & Dalbergia inundata & Anavilhanas/AM \\
\hline INPA 650 & Clitoria amazonum & Ponta Negra/AM \\
\hline INPA 657 & Entada polyphylla & INPA/CPCA \\
\hline INPA 658 & Entada polyphylla & INPA/CPCA \\
\hline INPA 671 & Inga edulis & INPA/CPCA \\
\hline INPA 673 & Abrus tenuiflorus & Maracá/RR \\
\hline INPA 678 & Andira riveriana & INPA/CPCA \\
\hline
\end{tabular}

* Source: Soil Microbiology Laboratory - CPCA/ INPA

Table 2. Tolerance score ranges for evaluating rhizobia growing on YMA medium.

\begin{tabular}{lc}
\hline TOLERANCE & SCORE RANGES \\
\hline Sensitive & $1.00-2.00$ \\
Moderate tolerance & $2.06-3.00$ \\
Tolerant & $3.06-4.00$ \\
\hline
\end{tabular}




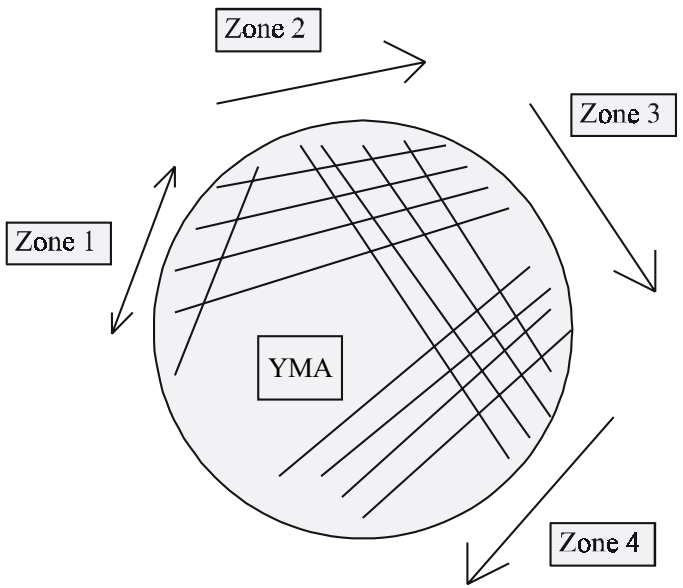

Platinum loop must be sterilized for each streaking zone.

Zone 1. One line. Streaking from a loop, several times in both directions indicated by the arrow.

Zone 2. Four lines streaked in only one direction (indicated by the arrow). Streaking once per line.

Zones 3 and 4 . As for zone 2.

Figure 1. Streaking procedure in Petri dishes with YMA medium for rhizobia growth evaluation.

\section{RESULTS AND DISCUSSION}

Tolerant rhizobia (INPA 078, Fig. 3A) presented scores of 4.00 at both pHs at 6,9 or 12 days after streaking in the Petri dishes, while sensitive strain (INPA 641, Fig. 3B) never reached this score. INPA 642 (Fig. $3 \mathrm{C})$ presented a moderate tolerance to $\mathrm{pH} 4.5$.

The method was successful for quantitative evaluation of rhizobia tolerance to acidity. It was possible to separate rhizobia strains statistically, and with low variation among the four replicates for each strain at each $\mathrm{pH}$ (Table 3). The standard deviations in general were very low, with the majority being between 0.00 and 0.10 . Only five of the 31 strains presented standard deviations higher than 0.10 . At 18 days of growth, 15 of the 31 strains presented high growth at $\mathrm{pH} 4.5$, being statistically similar or
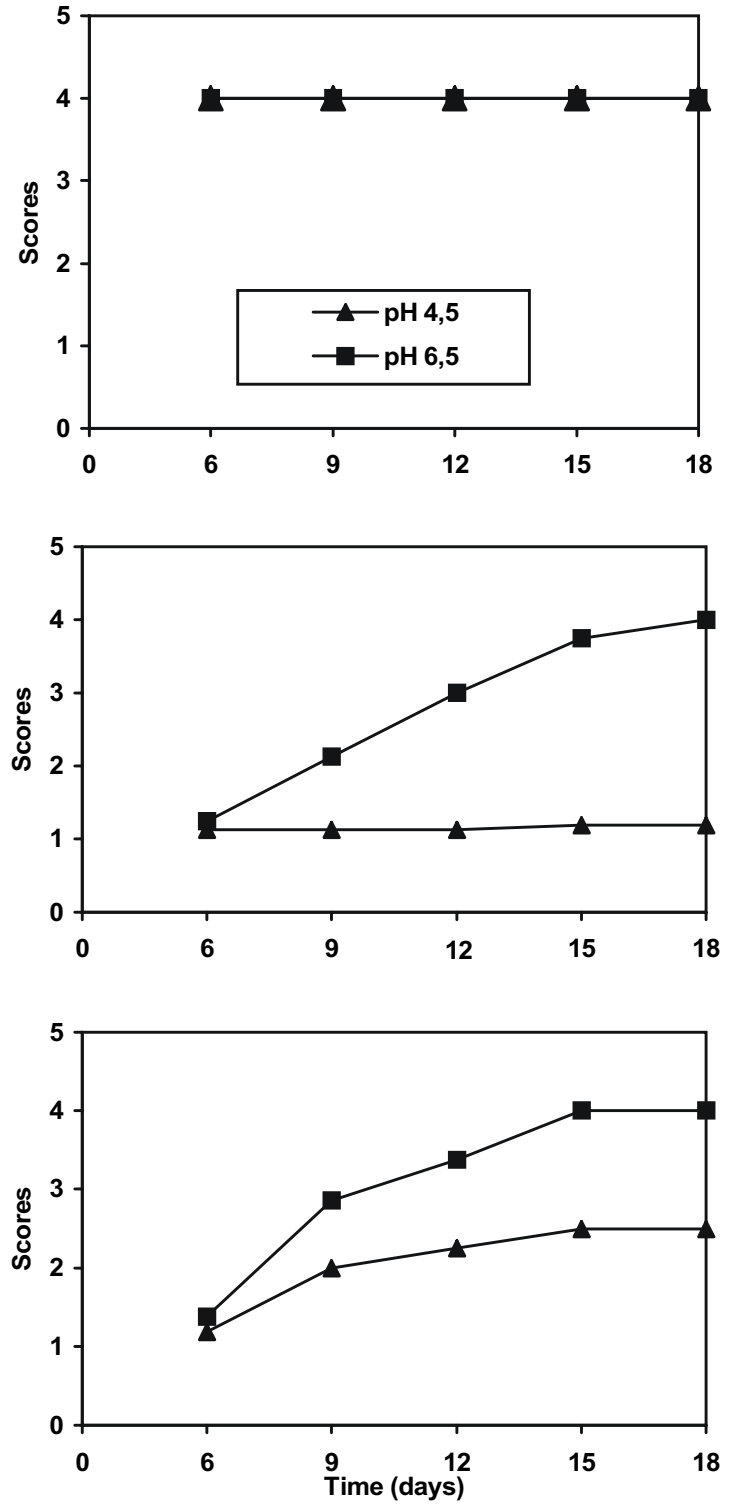

Figure 3. Different degrees of acidity tolerance of rhizobia grown at $\mathrm{pH} 4.5$ and 6.5 during 18 days on YMA medium. A. tolerant strain INPA 078; B. sensitive strain INPA 641; C. moderately tolerant strain INPA 642.

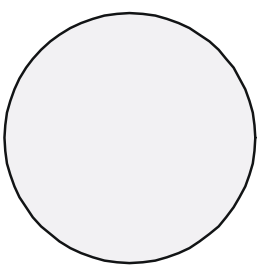

Score 1.00

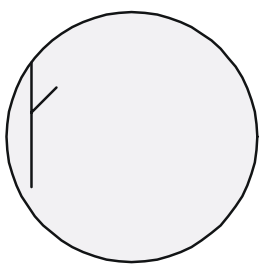

Score 1.25

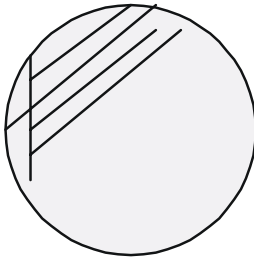

Score 2.00

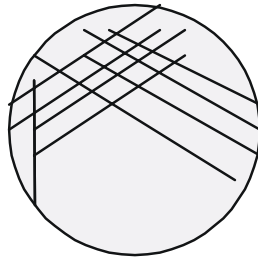

Score 3.00

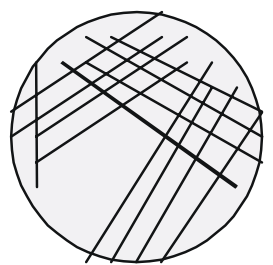

Score 4.00

Figure 2. Scores for rhizobia growth in Petri dishes with YMA medium. 
Table 3. Mean (sd) ${ }^{2}$ growth of root nodule bacteria on YMA medium at $\mathrm{pH} 4.5$ and 6.5. Means of four replications.

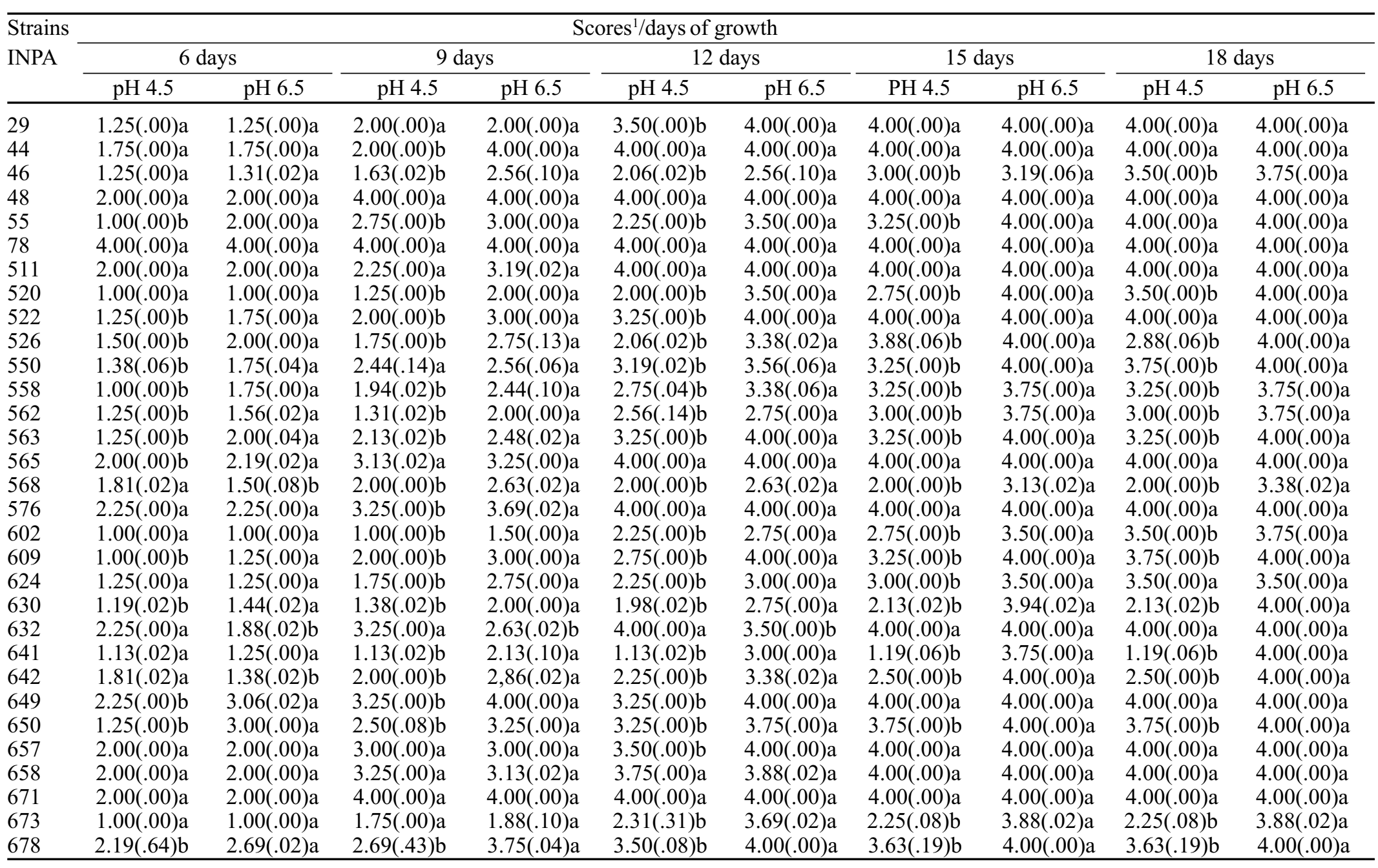

- Scores: $1.00=$ "no visible" growth; $4.00=$ maximum growth

$2-(\mathrm{sd})=$ standard deviation.

3 - Means with the same letter in a line (inside each date) are not statistically different (Tukey test at 5\%). 
equal to growth at $\mathrm{pH} 6.5$ : INPA $029,044,048,055$, $078,511,522,565,576,624,632,649,657,658$, and 671 .

This method also allows selection of strains without statistical analysis, by choosing those which grow well on the medium (scores $>3.00$ ). Using this less rigorous criterion of evaluation (without statistical analysis, Table 2), it is possible to include in this tolerance group the strains INPA 046, 520, $550,558,563,602,609,650$, and 678 , since they presented scores higher than 3.00 at $\mathrm{pH} 4.5$ at 18 days of growth.

Growth stabilization occurred from day 6 to day 15 after streaking the plates. Consequently the time of growth may also be used for selection, since those strains that present higher scores with less time of growth indicate they are more tolerant to low $\mathrm{pH}$. Thus, at 9 days of growth, it was possible to verify, statistically, that the strains INPA 048, 078, and 671 presented 4.00 scores at both $\mathrm{pHs}$. The less rigorous evaluation, using the Table 2 as reference, also includes in this highly tolerant group the strains INPA $511,565,576,632,649$, and 658 , which presented scores higher than 3.00 at this time of evaluation.

When bromocresol green was used to evaluate visual changes of medium $\mathrm{pH}$, only strain INPA 046 presented the ability to decrease medium $\mathrm{pH}$. All the other strains presented no visual $\mathrm{pH}$ changes in the medium. The ability to decrease the $\mathrm{pH}$ may have affected in some way the tolerance of the strain INPA 046, which reached scores higher than 3.00 only after 18 days of growth. None of the strains presented a visual change of the medium $\mathrm{pH}$, which could be a mechanism to neutralize the acidity, as observed by other authors $(2,13,19)$.

The method proved useful for quantitative evaluation of rhizobia tolerance at low $\mathrm{pH}$. It is very easy and fast for screening a large number of rhizobia isolates under laboratory conditions. Statistical analysis may be used when accuracy is necessary. This method also evaluated fastgrown rhizobia (Rhizobium leguminosarum bv. phaseoli) (Oliveira, L.A. and Graham, P.H., unpublished results) for this purpose, as well as for evaluating tolerance to other soil constraints, such as aluminum toxicity (12). However, it is only the first step in rhizobia selection. Tests for nitrogen fixation effectiveness, competitiveness for nodule sites and soil persistence $(1,5,8,9,10,11)$ must be done, before recommendation of these tolerant strains as inoculants.

\section{ACKNOWLEDGEMENT}

We thank Dr. Charles R. Clement for suggestions and correction of the English. Supporting project CNPq n ${ }^{\circ}$ 520814/96.7 (RE).

\section{RESUMO}

\section{Avaliação quantitativa da tolerância de rizóbios à acidez.}

A quantificação da tolerância à acidez em testes de laboratório pode ser o primeiro passo na seleção de estirpes de rizóbios para a Amazônia. O presente método avaliou isolamentos de rizóbios em placas de Petri contendo meio YMA com pHs 6,5 (controle) e 4,5, usando notas de 1,0 (sensíveis, sem crescimento visual), até 4,0 (tolerantes, máximo crescimento). As avaliações foram realizadas aos 6 , $9,12,15$ e 18 dias de crescimento. O método permite selecionar preliminarmente, rizóbios isolados de solos da Amazônia, com precisão estatística. Entre as 31 estirpes inicialmente testadas, as estirpes INPA 048,078 e 671 apresentaram notas iguais a 4,0 em ambos os pHs testados após os 9 dias de crescimento. Ao se analisar as estirpes usando um sistema menos rigoroso (nota de crescimento acima de 3,0), foi possível incluir também neste grupo, as estirpes INPA 511, 565, 576, 632, 649 e 658, que cresceram na zona mais diluída (zona 4) após 9 dias. As estirpes tolerantes devem ser testadas para eficácia na fixação de nitrogênio, competição por sítios de nódulos e persistência no solo antes de serem recomendadas para o uso em inoculantes comerciais.

Palavras-chave: Rhizobia, tolerância ao pH, Amazônia

\section{REFERENCES}

1. Carter, J.M.; Tieman, J.S.; Gibson, A.H. Competitiveness and persistence of strains of rhizobia for faba bena in acid and alkaline soils. Soil Biol. Biochem., 27(4/5):617-623, 1995.

2. Keyser, H.H.; Munns, D.N. Tolerance of rhizobia to acidity, aluminum, and phosphate. Soil Sci. Soc. Am. J., 43:519-523, 1979.

3. Magalhães, F.M.M.; Magalhães, L.M.; Oliveira, L.A; Dobereiner, J. Ocorrência de nodulação em leguminosas florestais de terra firme nativas da região de Manaus-AM. Acta Amazonica, 12(3):509-514, 1982.

4. Nicholaides, J.J. III; Sanchez, P.A.; Bandy, D.E.; Villachica, J.H.; Coutu, A.J.; Valverde, C.S. Crop production systems in the Amazon Basin. In: Moran, E. (ed.). The Dilemma of Amazonian Development. Westview, New York, 1983, p. 101153. 
5. Oliveira, L.A.; Graham, P.H. Speed nodulation and competitive ability among strains of Rhizobium leguminosarum bv phaseoli. Arch. Microbiol., 153:311-315, 1990.

6. Oliveira, L.A.; Smith, T.J.; Bonetti, R. Efeito de adubações anteriores na nodulação e rendimento da soja e do feijão caupi num latossolo amarelo da Amazônia. R. Bras. Ci. Solo, 16:195-201, 1992.

7. Oliveira, L.A.; Sylvester-Bradley, R. Effect of different central amazonian soils on growth, nodulation, and occurrence of N2-fixing Azospirillum spp. in roots of some crop plants. Turrialba, 32(4):463-469, 1982.

8. Oliveira, L.A.; Vidor, C. Seleção de estirpes de Rhizobium japonicum em soja. I. Eficiência e especificidade hospedeira. R. Bras. Ci. Solo, 8:37-42, 1984a.

9. Oliveira, L.A.; Vidor, C. Seleção de estirpes de Rhizobium japonicum em soja. II. Capacidade competitiva por sítios de nódulos. R. Bras. Ci. Solo, 8:43-47, 1984 b.

10. Oliveira, L.A.; Vidor, C. Capacidade competitiva de estirpes de Rhizobium japonicum em solos com alta população deste Rhizobium. R. Bras. Ci. Solo, 8:49-55, 1984c.

11. Oliveira L.A., Vidor, C. Colonização, sobrevivência e competitividade de estirpes de Rhizobium japonicum. R. Bras. Ci. Solo, 8:57-62, 1984d.

12. Paiva, R.M.Q.; Oliveira, L.A. Seleção de estirpes de Bradyrhizobium para solos da Amazônia com fertilidade baixa e acidez elevada. Anais da VI Jornada de Iniciação Científica do INPA. Resumos Expandidos, 1997, p.231-234.
13. Reeve, W.G.; Tiwari, R.P.; Dilworth, M.J.; Glenn, A.R Calcium affects the growth and survival of Rhizobium meliloti. Soil Boil. Biochem., 25(5):581-586, 1993.

14. Saragoussi, M. Pequenos produtores rurais de terra-firme em três localidades do Estado do Amazonas: Principais problemas; Propostas de soluções. In: Ferreira, E.J.G.; Santos, G.M.; Leão, E.L.M.; Oliveira, L.A. (eds.). Bases Cientificas para Estratégias de Preservação e Desenvolvimento da Amazônia. INPA, Manaus, Vol. 2, 1993, p.107-122.

15. Somasegaran, P.; Hoben, H.J. Methods in legume-Rhizobium technology. Nif+TAL Project and MIRCEN, Hawaii, 1985, $365 \mathrm{p}$.

16. Souza, L.A.; Magalhães, F.M.M.; Oliveira, L.A. Avaliação do crescimento de Rhizobium de leguminosas florestais tropicais em diferentes meios de cultura. Pesq. Agropec. Bras., 19:165-8, 1984.

17. Sylvester-Bradley, R. Isolation and cultivation of Rhizobium strains for tropical forage legumes using acid media. In: X Reunion Latinoamericana de Rhizobiólogos, Maracay, Venezuela, 1980, p.315-322.

18. Vincent, J.M. A manual for the practical study of root-nodule bacteria. IBP Handbook, $\mathrm{n}^{\circ}$ 15, Blackwell Scientific Publ., Oxford. 1970, 164p.

19. Wood, M. A mechanism of aluminium toxicity to soil bacteria and possible ecological implications. Plant and Soil, 171:6369, 1995. 